DOI:10.24193/tras.60E.4

Published First Online: 2020/06/22

\section{THE DETERMINANTS \\ OF PUBLIC PENSION DEBT \\ IN U.S. STATES*}

\author{
Jae Young LIM
}

\section{Jae Young LIM}

Senior Researcher, Community Wellbeing Research Center, Seoul National University, Seoul, Korea

Tel.: 82-2-880-8530

E-mail: jaeyounglim@yahoo.com

\section{Abstract}

State and local governments across the United States of America (USA) were hit hard by the recent recession. The fiscal stress alerted the public to the increasing amount of public pension debt for which, despite snowballing levels of pension debt, the causes are unclear. This article examines the factors contributing to annual changes in unfunded public pension ratios, focusing in particular on public pension management (including investment performance, investment assumptions, and accounting practices). The data on pension debt for state defined benefit plans comes from the Pew Charitable Trusts for the period 2005 to 2015. Two methods (random-effects and general estimating equation) were used to verify the consistency of the results. These results showed that investment return decreases the annual change in the public pension debt while using a project unit credit method, and the implementation of the Government Accounting Standards Board (GASB) Statement 67 increase the annual change in the public pension debt. These findings illustrate the importance of public pension management in explaining public pension debt.

Keywords: annual change in unfunded pension ratios, investment return, project unit credit, GASB 67.
* Acknowledgments: This work was supported by the Ministry of Education of the Republic of Korea and the National Research Foundation of Korea (NRF-2016S1A3A2924563). 


\section{Introduction}

When the housing bubble burst in the late 2000s, it devastated state and local governments across the US. The nationwide fiscal stress this caused drew attention to the problem of public pension liabilities ${ }^{1}$. Some scholars estimate that state and local pension liabilities are as high as $\$ 4.43$ trillion (Novy-Marx and Rauh, 2011).

The gravity of the pension problems affecting state and local governments has led to an increase in research on public pensions. However, few studies have directly assessed the factors contributing to the annual change in unfunded public pension ratios at the aggregate state level. This study therefore examines the factors that might influence unfunded public pension liabilities, focusing primarily on dimensions of public pension management.

Data on pension debt for state defined benefit plans from 2005 to 2015 were obtained and two statistical methods were used to verify the consistency of the results (random-effects and general estimating equation). The results show that public pension management plays a sizable role in influencing public pension debt across U.S. states. For instance, investment return reduces the annual change in public pension debt while using a project unit credit method to calculate pension costs along with the implementation of the GASB 67 increases the annual change in public pension debt. This underlines the importance of public pension management, such as investment performance and accounting practices, in explaining public pension debt.

The presentation of the research is organized as follows: first, I discuss factors that might contribute to public pension debt, focusing on public pension management and, secondly, I discuss the data and specific variables used in the model. Finally, I present the empirical results along with a discussion of their implications, followed by several policy recommendations for public officials involved in public pension management.

\section{Theory and hypotheses}

In recent years, an increasing number of studies have explored public pension issues; this reflects the growing importance of such pensions in the public arena. From these studies, several themes have emerged. One such theme is the relationship between state politics and public pensions (Coggburn and Kearney, 2010; Kiewiet, 2010; Thom, 2013a and 2013b; Anzia and Moe, 2017). Public unions have also been subject to scholarly inquiry (Mitchell and Smith, 1994; Munnell et al., 2011a). A third, flourishing arena of research is the management of public pension boards concerned with public pension performance and state bond ratings (Hess, 2005; Andonov et al., 2018; Dove et al., 2018). The estimation of public pension liabilities with respect to discount

1 Unfunded (public) pension liabilities refer to unfunded actuarial accrued liabilities for state defined benefit plans. To avoid using technical jargon, the article refers to unfunded pension liabilities rather than the more technical term. In addition, public pension debt is used interchangeably with unfunded pension liabilities. This latter term is limited to U.S. states; it is not applicable to local governments. 
rates and their sustainability have also garnered scholarly attention (Brown and Wilcox, 2009; Novy-Marx and Rauh, 2009, 2011; Waring, 2012; Chen and Matkin, 2017) as has an ideal funding level for public pensions (Bohn, 2011; Munnell et al., 2011a). The investment patterns of public pension assets have also raised concerns (Lucas and Zeldes, 2009; Pennacchi and Rastad, 2011). In addition, economists have examined the impact of public pensions on labor markets and practices (Munnell et al., 2007; Schieber, 2011; Goldhaber et al., 2017) along with the political and economic aspects of public pension liabilities (Schneider and Damnanpour, 2002; Glaeser and Ponzetto, 2014; Kelley, 2014). Scholars have also studied the impact of fiscal institutions such as budget stabilization funds and fiscal conditions on public pensions (Clair, 2012; Chen, 2018). Several scholars have probed the legal structures of public pensions and the possibilities for pension reform (Monahan, 2010, 2012, 2015, 2017; Fitzpatrick and Monahan, 2015; Aubrey and Crawford, 2017).

Despite a growing number of studies researching public pensions, few have examined the factors contributing to public pension debt using the 'annual change in unfunded public pension ratios' measure. This study does so with a specific focus on the dimensions of public pension management.

\subsection{Public pension management: Investment return and assumption}

Monahan (2015) argued that it is not easy to compare the costs of pension plans due to differences in underlying investment assumptions. Despite being ambiguous and often mystifying, the investment assumption rate - often used interchangeably with 'discount rate' - plays a vital role in determining pension costs. For the same pension plan, a stronger discount rate can make future liabilities seem much lower than they actually are (Munnell, 2012). A majority of states and local governments have anticipated the expected return on pension assets to be approximately $7.5 \%$. This overly optimistic assumption enables states and local governments to put less than their required contribution into the pension pot. Unlike public pension plans, private companies have, in recent years, discounted their pension liabilities at an average rate of $4.7 \%$ to account for real-life circumstances (The Economist, 2013).

Novy-Marx and Rauh $(2009,2011)$ have argued that the serious shortfall in pension funds facing states and local governments stems in part from optimistic actuarial assumptions over the years. Although these assumptions might have been acceptable in the robust economy of the 1990s, such optimism could lead to a calamity in leaner economic times. With the application of a realistic discount rate, pension liabilities of around $\$ 900$ billion can jump to $\$ 3.2$ trillion or even higher to $\$ 4.43$ trillion (Novy-Marx and Rauh, 2011). The former assumes that pension liabilities are equivalent to states' general obligation debt; whereas, in the latter, a discount rate is considered a zero-coupon Treasury yield. Regardless of whether states should use a 'risk-free' rate actuarial - because a pension payment is bound to be made in the future - (Novy-Marx and Rauh, 2011; Waring, 2012), an optimistic rate is equated with a decline in pension liabilities. 
The close relationship between an assumed rate and pension debt also applies to the relationship between an investment return and pension debt; in fact, a discount rate is a hypothesized rate while an investment return is a realized rate. As such, it is also critical in understanding the dynamics of pension debt. For instance, an improvement in investment yields on pension assets can significantly shrink the size of the pension debt. A healthy economy and accompanying investment returns can hide the size of the public pension debt whereas a poor economy can quickly magnify the problem (Monahan, 2017). Based on reasonable expectations regarding the relationship between investment return, investment assumption rate and public pension debt, the following hypotheses were constructed for empirical testing:

- Hypothesis 1: An increase in investment return will be associated with a decrease in the annual change in unfunded pension ratios, and

- Hypothesis 2: An increase in investment assumptions will be associated with a decrease in the annual change in unfunded pension ratios.

\subsection{Public pension management: accounting practices}

Accounting practices can significantly influence the level of public pension debt. Regarding the accounting method, state plans primarily use the entry age normal while approximately $13 \%$ of plans employ the project unit credit method. For the entry age normal, employers 'frontload' future benefits; whereas in the project unit credit employers are backloaded with pension obligations as a retirement horizon approaches (Munnell, 2012, p. 52). Assuming that employers fully fund their pension obligations, they would have to set aside fewer pension assets by using the project unit credit. Thus, the project unit credit is a less stringent method of funding than using the entry age normal (Munnell, 2012). However, having fewer assets to work with will dampen investment opportunities and eventually lead to larger public pension debt.

It is also important to note any changes to accounting methods that influenced the way pensions were calculated during the period from 2005 to 2015. The Government Accounting Standards Board announced the GASB 67 in 2012 and it took effect in 2014 (Farmer and Maciag, 2015). The GASB 67 requires states to adopt a realistic discount rate. The change adopted the blend rate whereby states that regularly make their full annual required contributions can use an assumed investment return, whereas those not doing so are forced to use a market rate. An optimistic discount rate with its overly positive assumptions about future investment returns conceals the true state of public pension funding. The change exposed several states to the grim reality of worsening pension debt. For example, the state of Kentucky had to lower its investment return assumption by $2 \%$, which meant that it suddenly experienced a $6 \%$ increase in pension debt from 2013 to 2014. The change in method could help explain the variations in unfunded ratios across states that occurred in 2014 and 2015 (Farmer and Maciag, 2015). As such, we arrived at:

- Hypothesis 3: States using a project unit credit method will experience an increase in the annual change in unfunded pension ratios, and 
- Hypothesis 4: Implementing the GASB 67 will be associated with an increase in the annual change in unfunded pension ratios.

\section{Variables and measurement}

\subsection{Dependent variable}

To test the hypotheses, the model, including the following dependent and explanatory variables, was estimated. The dependent variable in the model was the annual change in unfunded pension ratios. The unfunded ratio itself is equal to:

$$
\left(1-\left(\frac{\text { Actuarial Value of Assets }}{\text { Actuarial Accrued Liability }}\right)\right) \times 100(1)
$$

Because the explanatory variables were annual measures, it was appropriate to use 'the annual change' in unfunded pension ratios to examine annularity rather than unfunded pension ratios because the latter is a cumulative measure. The data came from the Pew Charitable Trusts (2018), and covered the period 2005 to 2015. These variables accounted for all the defined benefit plans (238 plans) to which the state contributes and/or is legally liable for benefits (The Pew Charitable Trusts, 2015, 2018). Figures 1-3 show the magnitude of public pension debt where Figure 3 in particular illustrates the trajectory of the dependent variable from 2005 to 2015.

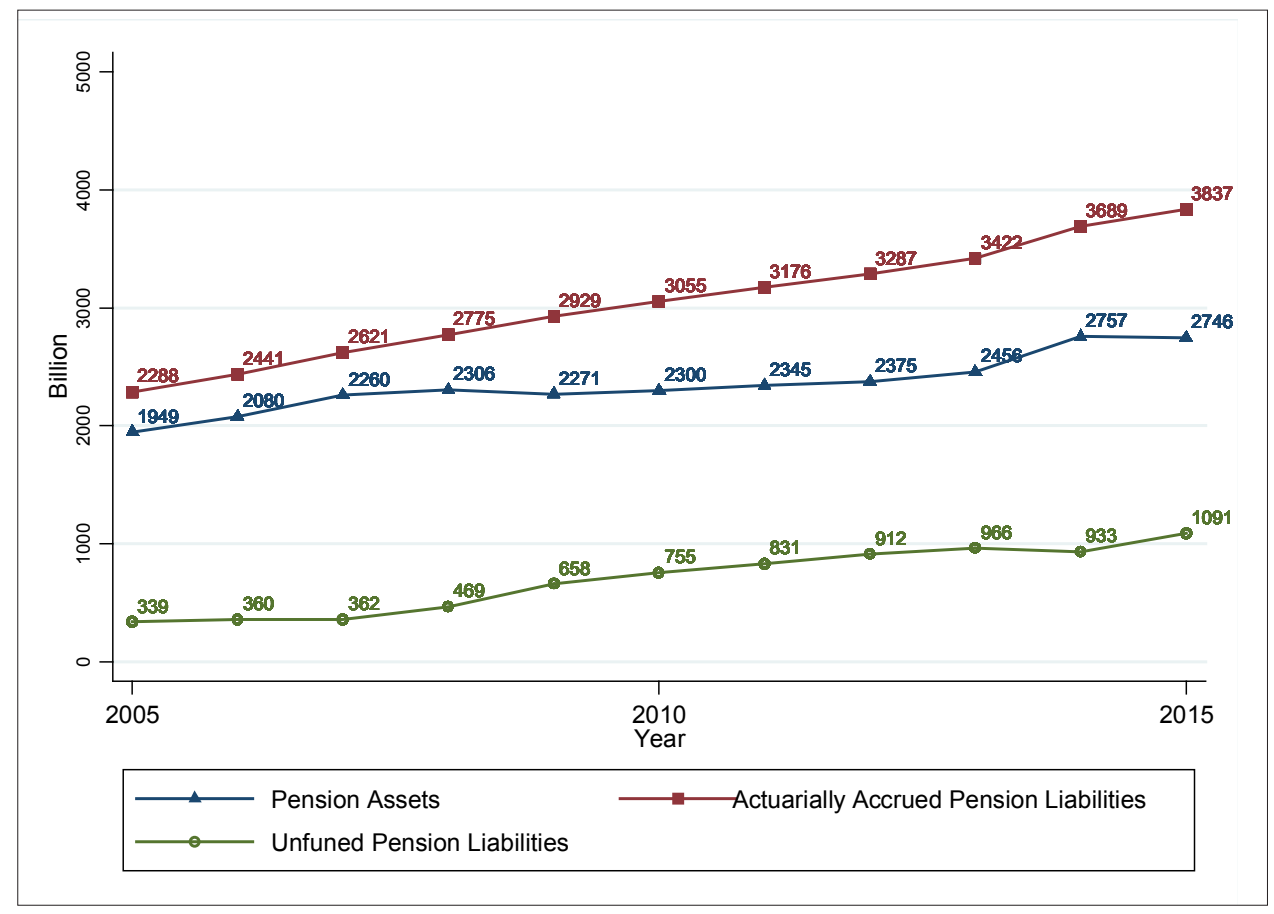

Figure 1: Change in pension assets, actuarial accrued pension liabilities, and unfunded pension liabilities, 2005-2015 


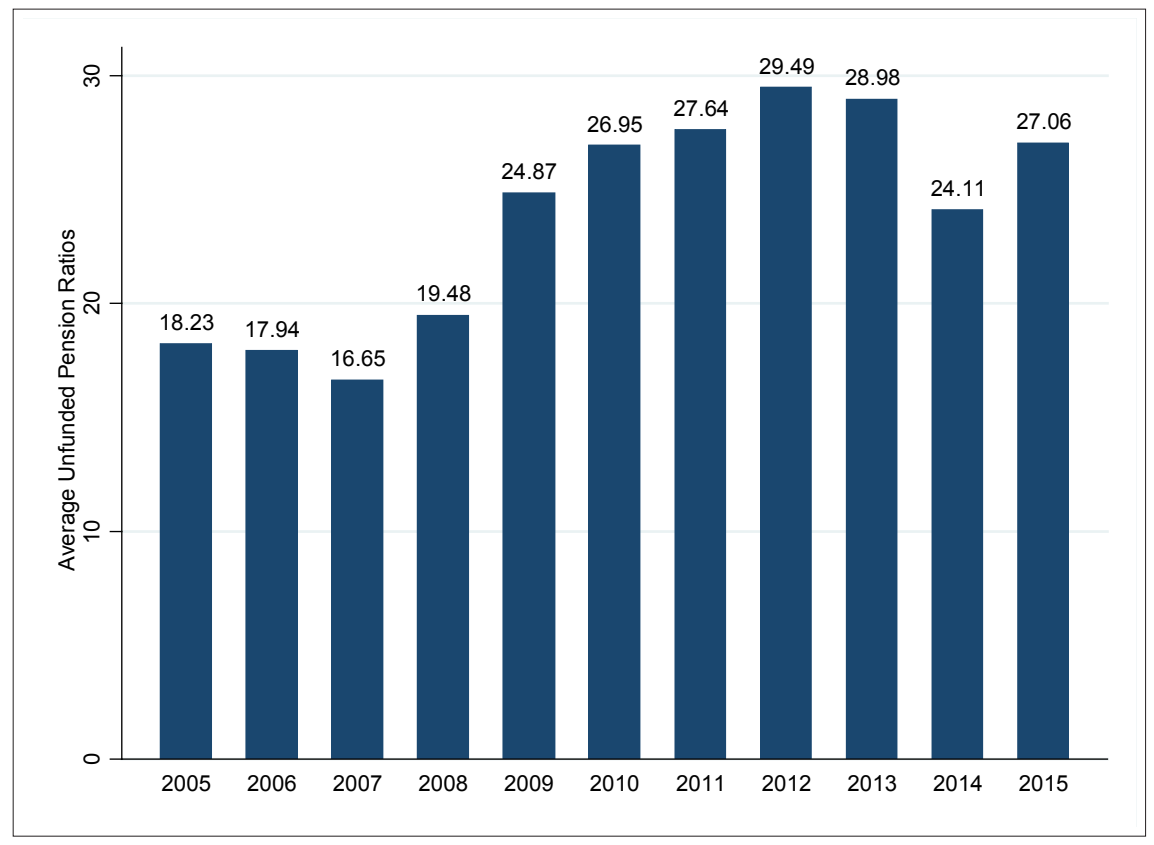

Figure 2: Average unfunded public pension ratios, 2005-2015

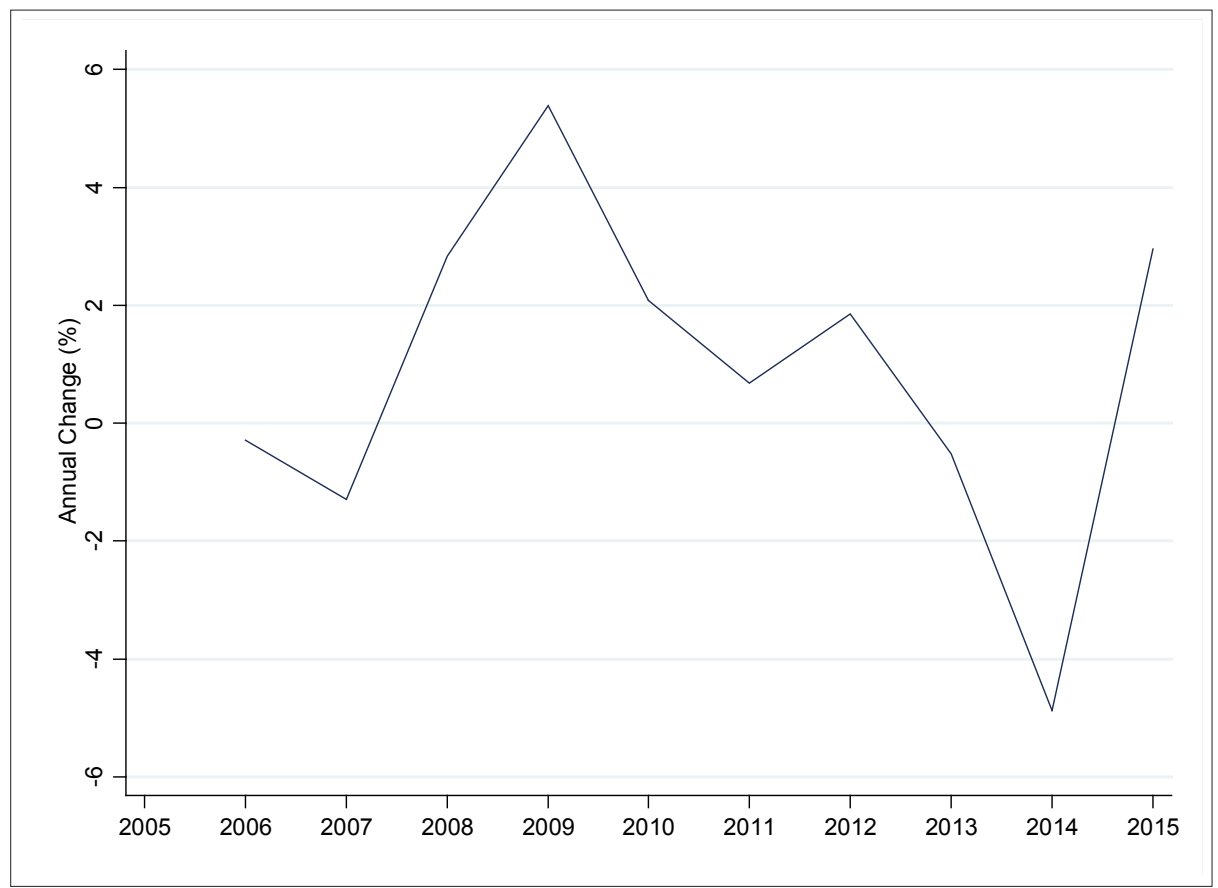

Figure 3: Annual change in unfunded pension ratios, 2005-2015 


\subsection{Explanatory variables}

Five variables were employed to explore public pension management: investment return, investment assumption, project unit credit, GASB 67, and active plan members. Because the dependent variable was an aggregate measure, it would have been ideal to have state-level aggregate data available. Unfortunately, however, most states manage multiple pension plans, and it is difficult to derive aggregate state-level measures. Thus, for each state, I used the largest representative defined benefit plan (in terms of total pension assets) for the variables noted above.

The investment return is a five-year return and a ratio; the investment return assumption is also a ratio. The project unit credit was a dummy variable coded as 1 if the representative plan in each state employed the project unit credit method to estimate actuarial pension costs and 0 otherwise. Active plan members were logged to correct for the skewness resulting from large numbers. The final public pension management variable was the GASB 67, which was a dummy variable coded as 1 if implemented in a given year and 0 otherwise.

Table 1 shows the 50 representative plans that were selected to identify plan-specific pension management characteristics (Public Plans Data, 2001-2016).

Table 1: Representative largest defined benefit plans in each state

\begin{tabular}{ll}
\hline \multicolumn{1}{c}{ States } & \\
\hline Alabama & Teachers Retirement System \\
Alaska & Public Employees' Retirement System \\
\hline Arizona & State Retirement System \\
Arkansas & Teachers Retirement System \\
\hline California & Public Employees Retirement System \\
\hline Colorado & School Division \\
\hline Connecticut & Teachers' Retirement System \\
\hline Delaware & State Employees' Pension Plan \\
\hline Florida & Retirement System \\
Georgia & Teachers' Retirement System \\
Hawaii & Employees' Retirement System \\
Idaho & Public Employee Retirement Fund - Base Plan \\
\hline Illinois & Teachers' Retirement System \\
Indiana & State Teachers' Retirement Fund \\
\hline lowa & Public Employees' Retirement System \\
\hline Kansas & Public Employees' Retirement System \\
\hline Kentucky & Teachers' Retirement System \\
\hline Louisiana & Teachers Retirement System of Louisiana \\
\hline Maine & Public Employees Retirement System \\
\hline Maryland & Teachers' Retirement and Pension System \\
\hline
\end{tabular}




\begin{tabular}{|c|c|}
\hline States & Plans \\
\hline Massachusetts & Teachers' Retirement System \\
\hline Michigan & Public School Employees' Retirement System \\
\hline Minnesota & Teachers Retirement Fund \\
\hline Mississippi & Public Employees' Retirement System \\
\hline Missouri & Public School Retirement System \\
\hline Montana & Public Employees' Retirement System - Defined Benefit Retirement Plan \\
\hline Nebraska & Public Employees Retirement System-Schools \\
\hline Nevada & Public Employees' Retirement System \\
\hline New Hampshire & Employees Group \\
\hline New Jersey & Teachers' Pension and Annuity Fund \\
\hline New Mexico & Public Employee's Retirement System \\
\hline New York & New York State and Local Retirement System \\
\hline North Carolina & Teachers' and State Employees' Retirement System \\
\hline North Dakota & Teachers' Fund for Retirement \\
\hline Ohio & Public Employees Retirement System \\
\hline Oklahoma & Teachers' Retirement System \\
\hline Oregon & Public Employees' Retirement System \\
\hline Pennsylvania & Public School Employees' Retirement System \\
\hline Rhode Island & Employees' Retirement System - Teachers \\
\hline South Carolina & South Carolina Retirement System \\
\hline South Dakota & South Dakota Retirement System \\
\hline Tennessee & State Employees, Teachers, and Higher Education Employees' Pension Plan \\
\hline Texas & Teacher Retirement System \\
\hline Utah & Public Employees Noncontributory Retirement System \\
\hline Vermont & Teachers' Retirement System \\
\hline Virginia & Virginia Retirement Systems \\
\hline Washington & Public Employees' Retirement System \\
\hline West Virginia & Teachers' Retirement System \\
\hline Wisconsin & Wisconsin Retirement System \\
\hline Wyoming & Public Employees' Pension Plan \\
\hline
\end{tabular}

For control variables, I relied on the state's fiscal constraints, state politics, and state fiscal conditions. Scholars argue that fiscal constraints such as tax and expenditure limitations (TELs) play a substantial role in explaining a state's fiscal behavior (Poterba, 1994; Alt and Lowry, 1994; Matsusaka, 1995; Alesina and Bayoumi, 1996; Mullins and Joyce, 1996; Shadbegian, 1999; Pollack, 2003; Rose, 2006; Brunori, 2007, 2011; Martin, 2008; Mathews and Paul, 2010). To capture institutional fiscal constraints for each state I used the tax and expenditure limitations (TELs) index developed by 
Kallen (2017). The data ranged from 0 (states such as Alabama and North Dakota) to 28 (Missouri), and the total score was built on the following six categories: 'Type of TEL,' 'Statutory/Constitutional', 'Growth Restriction', 'Method of Approval', 'Override Provisions', and 'Exemptions'. This measure of TELs is superior to the simple dummy variable used in many other studies (e.g., Mason, 2005; McGuire and Rueben, 2006) as it reflects the diversity of TELs measures across states.

State politics and public unions were also accounted for in the model. Scholars have found that states controlled by the Democratic Party tend to spend and tax more, and are more likely to support employee-friendly policies and public unions than the Republican Party (Blais et al., 1993; Poterba, 1996; Shadbegian, 1999; Marschall and Ruhil, 2005). Popular media outlets continue to blame public unions for their outsized pension benefits and debt (Lowenstein, 2008; Greenhut, 2009; Malanga, 2010; Erie et al., 2011), although empirical findings on the effects of public unions on public pension debt and benefits are inconclusive (Mitchell and Smith, 1994; Munnell et al., 2011b). Thus, public unions may cut both ways and therefore it was appropriate to see what the data would reveal. State political party variables were lagged at $\mathrm{t}-1$, as decisions regarding current budget outcomes are made in the previous year (Budge and Hofferbert, 1990). These variables included Democratic membership in the state house at $\mathrm{t}-1$ (\%), Democratic membership in the state senate at $\mathrm{t}-1$ (\%), Democratic governor at $\mathrm{t}-1$ (dummy), unified Democratic control at $\mathrm{t}-1$ (dummy), and unified Republican control at $\mathrm{t}-1$ (dummy). The public union variable consisted of public union membership (\%) (Hirsch and MacPherson, 2003; updated). An interaction term between unified Republican control at $\mathrm{t}-1$ and public union membership was also included in the model to account for potential relationships between politics and public unions.

Finally, the model accounted for fiscal conditions that may influence public pension debt. Unlike federal governments, states and local governments are constrained by having to balance their budgets, even in the midst of a fiscal crisis, and often cut spending or raise revenue during economic downturns. As such, it is critical to account for the fiscal conditions of states when accounting for fiscal outcomes such as public pension debt. Well-known variables for identifying fiscal stress include unemployment rates (Mitchell and Smith, 1994), year-end general fund balance (Wilson, 1983; Wilson and Howard, 1984; National Council of State Legislature, 1987; Raman and Wilson, 1990; Chaney et al., 2002), and long-term debt (Wilson, 1983; Denison et al., 2006). Both long-term debt and year-end general fund balance were expressed as a share of total state revenue to avoid severe right skewness due to the large numbers involved. Table 2 shows the measurement and data sources for the variables while Table 3 presents the descriptive statistics. 
Table 2: Measurement of dependent and explanatory variables

\begin{tabular}{|c|c|c|}
\hline Variable & Measurement & Sources and Remarks \\
\hline $\begin{array}{l}\text { Annual change in } \\
\text { unfunded pension ratios }\end{array}$ & Percentage & $\begin{array}{l}\text { The Pew Charitable Trusts (2018) } \\
\text { Unfunded Ratio: } \\
\qquad\left(1-\left(\frac{\text { Actuarial Value of Assets }}{\text { Actuarial Accrued Liability })}\right)\right) \times 100\end{array}$ \\
\hline 5-year investment return & Percentage & $\begin{array}{l}\text { Public Plans Data. 2001-2016. Center for Retire- } \\
\text { ment Research at Boston College, Center for State } \\
\text { and Local Government Excellence, and National } \\
\text { Association of State Retirement Administrators. }\end{array}$ \\
\hline Investment assumption & Percentage & $\begin{array}{l}\text { Public Plans Data. 2001-2016. Center for Retire- } \\
\text { ment Research at Boston College, Center for State } \\
\text { and Local Government Excellence, and National } \\
\text { Association of State Retirement Administrators. }\end{array}$ \\
\hline Project unit credit & Indicator & $\begin{array}{l}\text { Public Plans Data. 2001-2016. Center for Retire- } \\
\text { ment Research at Boston College, Center for State } \\
\text { and Local Government Excellence, and National } \\
\text { Association of State Retirement Administrators. }\end{array}$ \\
\hline GASB 67 & Indicator & GASB (2012) \\
\hline Logged active plan members & $\begin{array}{l}\text { Values ranging } \\
\text { from } 9.17 \text { to } 13.67\end{array}$ & $\begin{array}{l}\text { Public Plans Data. 2001-2016. Center for Retire- } \\
\text { ment Research at Boston College, Center for State } \\
\text { and Local Government Excellence, and National } \\
\text { Association of State Retirement Administrators. }\end{array}$ \\
\hline $\begin{array}{l}\text { Tax and expenditure } \\
\text { limitation index }\end{array}$ & $\begin{array}{l}\text { Values ranging } \\
\text { from } 0 \text { to } 30\end{array}$ & Kallen (2017) \\
\hline $\begin{array}{l}\text { Democratic membership } \\
\text { in the state house at } t-1\end{array}$ & Percentage & National Council of State Legislatures (2015) \\
\hline $\begin{array}{l}\text { Democratic membership } \\
\text { in the state senate at } t-1\end{array}$ & Percentage & National Council of State Legislatures (2015) \\
\hline Democratic governor at t-1 & Indicator & National Council of State Legislatures (2015) \\
\hline $\begin{array}{l}\text { Unified Democratic State } \\
\text { at t-1 }\end{array}$ & Indicator & National Council of State Legislatures (2015) \\
\hline $\begin{array}{l}\text { Unified Republican State } \\
\text { at t-1 }\end{array}$ & Indicator & National Council of State Legislatures (2015) \\
\hline Public Union Membership & Percentage & $\begin{array}{l}\text { - Percentage of public employed workers } \\
\text { who are union members } \\
\text { - Hirsch and Macpherson (2003; updated) }\end{array}$ \\
\hline $\begin{array}{l}\text { Unified Republican state at } \\
\text { t-1 * public union membership }\end{array}$ & $\begin{array}{l}\text { Values ranging } \\
\text { from } 0 \text { to } 70\end{array}$ & Interaction term \\
\hline Unemployment & Percentage & Local Area Unemployment Statistics (2017) \\
\hline $\begin{array}{l}\text { Long-term debt as share } \\
\text { of total state revenue }\end{array}$ & Percentage & $\begin{array}{l}\text { State and Local Government Finances by U.S. Cen- } \\
\text { sus Bureau (2016); Fiscal Survey of States (2016) }\end{array}$ \\
\hline $\begin{array}{l}\text { Year-end general fund balance } \\
\text { as share of total state revenue }\end{array}$ & Percentage & Fiscal Survey of States (2016) \\
\hline
\end{tabular}


Table 3: Descriptive statistics for all variables

\begin{tabular}{|c|c|c|c|c|c|}
\hline Variable & $\mathrm{N}$ & Mean & SD & Min & Max \\
\hline Annual change in unfunded pension ratios & 490 & 0.88 & 4.94 & -14.69 & 32.00 \\
\hline 5-year investment return & 490 & 6.79 & 4.18 & -1.23 & 16.20 \\
\hline Investment assumption & 490 & 7.81 & 0.36 & 6.70 & 8.50 \\
\hline Project unit credit & 490 & 0.10 & 0.30 & 0.00 & 1.00 \\
\hline GASB 67 & 490 & 0.20 & 0.40 & 0.00 & 1.00 \\
\hline Logged active plan members & 490 & 11.54 & 0.99 & 9.17 & 13.67 \\
\hline Tax and expenditure limitation index & 490 & 9.12 & 8.36 & 0.00 & 28.00 \\
\hline Democratic membership in the state House at t-1 & 490 & 51.25 & 16.32 & 13.33 & 92.00 \\
\hline Democratic membership in the state Senate at t- 1 & 490 & 49.80 & 17.89 & 13.33 & 96.00 \\
\hline Democratic governor at t-1 & 490 & 0.48 & 0.50 & 0.00 & 1.00 \\
\hline Unified Democratic state at $\mathrm{t}-1$ & 490 & 0.34 & 0.47 & 0.00 & 1.00 \\
\hline Unified Republican state at t-1 & 490 & 0.37 & 0.48 & 0.00 & 1.00 \\
\hline Public union membership (\%) & 490 & 33.11 & 18.35 & 2.70 & 72.40 \\
\hline United Republican state at $t-1$ * public union membership & 490 & 8.35 & 14.08 & 0.00 & 70.00 \\
\hline Unemployment & 490 & 6.56 & 2.16 & 2.40 & 13.90 \\
\hline Long-term debt as share of total state revenue & 490 & 170.84 & 89.73 & 34.01 & 621.60 \\
\hline $\begin{array}{l}\text { Year-end general fund balance as share of total state } \\
\text { revenue }\end{array}$ & 490 & 4.97 & 9.96 & -118.70 & 65.08 \\
\hline
\end{tabular}

* Note: Nebraska is not included in the model due to its unicameral legislature.

\section{Findings}

The model was estimated using two methods: random-effects (RE) and general estimating equation (GEE). The two models also controlled for year dummies, whose results are not reported in the table. The results from the two models were consistent and only a few differences were evident in terms of coefficients and standard errors. Although the fixed effects model is ideal for eliminating potential sources of omitted variable bias, a Hausman test result (probabilities $=0.72$ ) indicated that the RE was appropriate in this case. Thus, the RE model was used first, rather than a fixed-effects model, with standard errors clustered around states.

The results from the GEE equation are also shown here as they provide significant advantages for the panel data. The GEE equation is an extension of a generalized linear model (Liang and Zeger, 1986; Zeger and Liang, 1986) and was also appropriate, especially given that cross-sectional panels are fraught with correlated data. This often leads to the violation of homoskedasticity and, consequently, introduces correlated error terms (Kmenta, 1986; Liang and Zeger, 1986; Zeger and Liang, 1986).

Because variance within each panel was likely to be heteroskedastic, Huber-White standard errors were employed to produce a robust estimate as well as correlational error structures of $\mathrm{AR}(1)$, assuming that data in the previous year influence the 
current year's data and lead clustered errors (Zorn, 2001). Table 4 shows the results for the two models. The $\chi 2$ statistic was 503.84 for the RE model and 594.20 for the GEE model; both numbers indicate that the two models fit the data well.

Table 4: Factors contributing to the annual change in unfunded pension ratios (RE and GEE)

\begin{tabular}{|c|c|c|c|c|}
\hline \multirow{2}{*}{$\begin{array}{l}\text { Explanatory Variable } \\
\text { 5-year investment return }\end{array}$} & \multicolumn{2}{|c|}{$\begin{array}{c}\text { Annual Change in Unfunded } \\
\text { Pension Ratios (RE) }\end{array}$} & \multicolumn{2}{|c|}{$\begin{array}{c}\text { Annual Change in Unfunded } \\
\text { Pension Ratios (GEE) }\end{array}$} \\
\hline & -0.493 & {$[0.129]^{\star \star \star}$} & -0.486 & {$[0.123]^{\star \star \star}$} \\
\hline Investment assumption & -0.228 & {$[0.401]$} & -0.177 & {$[0.381]$} \\
\hline Projected unit credit & 1.208 & {$[0.355]^{\star \star \star}$} & 1.302 & {$[0.314]^{\star \star \star}$} \\
\hline GASB 67 & 5.042 & {$[0.648]^{\star \star \star}$} & 5.045 & {$[0.627]^{\star \star \star}$} \\
\hline Logged active plan members & 0.246 & [0.182] & 0.240 & [0.173] \\
\hline Tax and expenditure limitation index & -0.027 & {$[0.020]$} & -0.029 & {$[0.019]$} \\
\hline $\begin{array}{l}\text { Democratic membership } \\
\text { in the state House at t-1 }\end{array}$ & 0.002 & {$[0.027]$} & 0.003 & {$[0.026]$} \\
\hline $\begin{array}{l}\text { Democratic membership } \\
\text { in the state Senate at t-1 }\end{array}$ & -0.006 & {$[0.020]$} & -0.007 & {$[0.019]$} \\
\hline Democratic governor at t-1 & -0.760 & {$[0.684]$} & -0.845 & {$[0.659]$} \\
\hline Unified Democratic state at t-1 & 0.364 & {$[0.415]$} & 0.460 & {$[0.399]$} \\
\hline Unified Republican state at t-1 & 0.535 & {$[0.747]$} & 0.582 & {$[0.752]$} \\
\hline Public union membership (\%) & 0.020 & {$[0.012]^{*}$} & 0.019 & {$[0.011]^{\star}$} \\
\hline $\begin{array}{l}\text { Unified Republican state at t-1 } \\
\text { * public union membership }\end{array}$ & -0.017 & {$[0.018]$} & -0.014 & {$[0.018]$} \\
\hline Unemployment & -0.072 & {$[0.129]$} & -0.057 & {$[0.122]$} \\
\hline $\begin{array}{l}\text { Long-term debt as share } \\
\text { of total state revenue }\end{array}$ & -0.002 & {$[0.002]$} & -0.001 & {$[0.002]$} \\
\hline $\begin{array}{l}\text { Year-end general fund balance } \\
\text { as share of total state revenue }\end{array}$ & 0.017 & {$[0.021]$} & 0.018 & {$[0.020]$} \\
\hline Constant & 2.592 & [4.138] & 2.281 & [3.958] \\
\hline Wald $X^{2}$ & \multicolumn{2}{|c|}{ 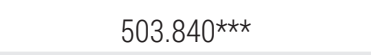 } & \multicolumn{2}{|c|}{$594.200 * \star \star$} \\
\hline Observations & \multicolumn{2}{|c|}{490} & \multicolumn{2}{|c|}{490} \\
\hline States & \multicolumn{2}{|c|}{49} & \multicolumn{2}{|c|}{49} \\
\hline
\end{tabular}

- Standard errors clustered around states in parentheses.

- Year fixed effects are included in the model but not shown in the table.

- Nebraska is not included in the model due to its unicameral legislature.

$-\star p \leq 0.10, * \star p \leq 0.05, * \star * p \leq 0.01$.

The two models show that the four variables significantly influenced the annual change in unfunded pension ratios. In terms of the main explanatory variables, the investment return was negatively associated with the annual change in unfunded pension ratios. This means that as an investment return increases, it helps slow the annual increase in public pension debt. This has implications for officials responsible 
for managing public pension assets in that it implies they should derive strategies or mechanisms to improve investment performance (discussed further in the final section). The two variables were positively associated with the annual change in unfunded pension ratios: project unit credit and the GASB 67. As hypothesized, using the project unit credit method inflates the unfunded liabilities vis-à-vis the entry age normal, as states put aside fewer assets with which to gain sizable investment returns. The GASB 67, the implementation of the accounting change that began in 2014, appears to influence the way states estimate their unfunded liabilities. This contributes to an increase in the annual change in unfunded ratios, worsening the level of pension debt. The negative impact of project unit credit and the GASB 67 raise two key points for officials in public pension management. First, they need to avoid using the project unit credit and instead adopt the entry age normal, which is a more robust accounting method for calculating public pension costs at the beginning of public employment. Second, public officials need to apply more a realistic investment assumption rate to their pension assets. The fact that using the GASB 67, which is more honest than the previous unconstrained investment assumption rate used by states, revealed a darker picture of public pension debt and should inform public officials of the need to adopt honest accounting methods and practices.

Finally, public union membership was also positively associated with the change in unfunded ratios, albeit at a weak, ten percent level. This indicates that increased public union membership increases the annual change in public pension debt. This highlights the need for public officials to work with public unions to find ways of dealing with public pension debt.

The results imply that the annual change in unfunded ratios is heavily influenced by dimensions of public pension management such as investment returns and accounting practices. Except for public unions (via public union membership), the lack of significance of other variables shows that fiscal constraints, state politics (except for public unions), and fiscal conditions do not play an important role in controlling the public pension debt affecting U.S. states. Although media outlets have decried political meddling with public pension management in the current pension crises, these political factors did not have any impact when combined with public pension management variables in the model.

\section{Implications for public officials}

This study sheds some light on factors affecting the annual change in unfunded public pension liabilities. The results show that dimensions of public pension management - such as investment returns, accounting methods (project unit credit), and accounting changes (GASB 67) - heavily influence public pension debt.

The results have important implications for the public officials responsible for managing public pension plans, who therefore need to adopt sound policy options. First, the results suggest that public officials need to work hard to boost their investment returns by scrutinizing their investment portfolios. One way to accomplish this 
is to diversify their pension asset investment strategies. In recent years many plans have relied too heavily on alternative investment methods, which entail paying heavy fees to investment firms. Moreover, this information is often hidden from the watchful eyes of the public (The Pew Charitable Trusts, 2015), eroding the accountability of public pension plans, especially in the eyes of current and retired public employees. If states invest too heavily in risky projects that produce few investment returns, they need to shift their assets to more stable choices such as index funds that correspond to stock market performance and those producing a stable, fixed income such as a treasury bond. Similarly, public officials need to adopt ways to regularly monitor public pension asset management.

If investment returns do not achieve the yields expected in terms of previously-established standards, stakeholders in public pension management need to determine what did not work and devise alternative strategies to improve pension performance. Naturally, there has to be a formal rule specifying this type of activity. Comparing the investment performance of pension plans with that of other states will also be beneficial for public officials aiming to improve pension asset performance. Enacting legislation that covers all these aspects will help bind public officials to better forms of public pension management.

Second, as Monahan (2015) argued, public officials need to adopt several enforcement mechanisms to ensure sound public pension management. This means that major decision makers in the public sector need to adopt state-of-the-art accounting management standards and practices. There should also be enforcement mechanisms to prevent public officials from utilizing accounting gimmicks for their own political gain. For instance, a practice such as the entry age normal method would ensure that states face larger pension liabilities at the beginning of public employment than would be the case for the project unit method. This would help states deal with such liabilities and enable them to build large pension assets for the investment of assets. More importantly, by clarifying the true state of their unfunded pension liabilities, sound accounting methods and practices will help states confront where they actually are in terms of numbers and what needs to be done. Adopting an accounting change such as the GASB 67 is also beneficial for public officials; although it generates worse numbers than when states were free to adopt their investment assumption rate, confronting this darker picture will eventually help public officials to prepare necessary strategies for dealing with public pension debt. By forcing public officials to use honest numbers, optimal accounting methods and practices will provide opportunities for public officials to alleviate public pension debt. Using a market rate for investment returns rather than the blended rate suggested by the GASB 67 is one option that can be used to reveal the true condition of the public pension debt and uncover the harsh reality for each state. Legislating enforcement mechanisms that force states to adopt best accounting methods and practices will go a long way in enabling states to identify problems and formulate solutions. 
Although this study has several merits, it also has certain limitations. For instance, the model includes a mixture of state-level and individual-level variables. Second, aggregation of the dependent variable at state level means the model might not have explored or accounted for some potentially crucial individual-level variables. Nevertheless, the study minimizes the potential threat of omitted variable bias by accounting for a comprehensive array of variables. Furthermore, examining the impact of factors on pension debt at the aggregate state level yields valuable macro-level insights that can inform both policymakers and the public regarding the steps that need to be taken.

\section{References:}

1. Alesina, A. and Bayoumi, T., 'The Costs and Benefits of Fiscal Rules: Evidence from U.S. States', NBER Working Paper 5614, June 1996, [Online] available at https://www.nber.org/ papers/w5614.pdf, accessed on August 15, 2018.

2. Alt, J.E. and Lowry, R.C., 'Divided Government, Fiscal Institutions, and Budget Deficits: Evidence from the States', 1994, American Political Science Review, vol. 88, no. 4, pp. 811-828.

3. Andonov, A., Hochberg, Y.V. and Rauh, J.D., 'Political Representation and Governance: Evidence from the Investment Decisions of Public Pension Funds', 2018, The fournal of Finance, vol. 73, no. 3, pp. 2041-2086.

4. Anzia, S.F. and Moe, T.M., 'Polarization and Policy: The Politics of Public-sector Pensions', 2017, Legislative Studies Quarterly, vol. 42, no. 1, pp. 33-62.

5. Aubrey, J. and Crawford, C.V., 'State and Local Pension Reform since the Financial Crisis. State and Local Pension Plans', Center for Retirement Research at Boston College, no. 54, January 2017, [Online] available at http://crr.bc.edu/wp-content/uploads/2016/12/slp_54. pdf, accessed on August 14, 2019.

6. Blais, A., Blake, D. and Dion, S., 'Do Parties Make a Difference? Parties and the Size of Government in Liberal Democracies', 1993, American Journal of Political Science, vol. 37, no. 1, pp. 40-62.

7. Bohn, H., 'Should Public Retirement Plans Be Fully Funded?', 2011, fournal of Pension Economics and Finance, vol. 10, no. 2, pp. 195-219.

8. Brown, J.R. and Wilcox, D.W., 'Discounting State and Local Pension Liabilities', 2009, American Economic Review, vol. 99, no. 2, pp. 538-542.

9. Brunori, D., Local Tax Policy: A Federalist Perspective, $2^{\text {nd }}$ edition, Washington, D.C.: Urban Institute Press, 2007.

10. Brunori, D., State Tax Policy: A Political Perspective, $3^{\text {rd }}$ edition, Washington, D.C.: Urban Institute Press, 2011.

11. Budge, I. and Hofferbert, R.I., 'Mandates and Policy Outputs: U.S. Party Platforms and Federal Expenditures', 1990, American Political Science Review, vol. 84, no. 1, pp. 111-133.

12. Bureau of Labor Statistics, 'Local Area Unemployment Statistics', 2017, [Online] available at http://www.bls.gov/lau/, accessed on August 25, 2018.

13. Chaney, B.A., Copley, P.A. and Stone, M.S., 'The Effect of Fiscal Stress and Balanced Budget Requirements on the Funding and Measurement of State Pension Obligations', 2002, fournal of Accounting and Public Policy, vol. 21, no. 4-5, pp. 287-313. 
14. Chen, G. and Matkin, D.S., 'Actuarial Inputs and the Valuation of Public Pension Liabilities and Contribution Requirements: A Simulation Approach', 2017, Public Budgeting \& Finance, vol. 37, no. 1, pp. 68-87.

15. Chen, G., 'Understanding Decisions in State Pension Systems: A System Framework', 2018, American Review of Public Administration, vol. 48, no. 3, pp. 260-273.

16. Clair, T., 'The Effect of Tax and Expenditure Limitations on Revenue Volatility: Evidence from Colorado', 2012, Public Budgeting and Finance, vol. 32, no. 3, pp. 61-78.

17. Coggburn, J.D. and Kearney, R.C., 'Trouble Keeping Promises? An Analysis of Underfunding in State Retiree Benefits', 2010, Public Administration Review, vol. 70, no. 1, pp. 97-108.

18. Denison, D., Hackbart, M. and Moody, M., 'State Debt Limits: How Many Are Enough?', 2006, Public Budgeting and Finance, vol. 26, no. 4, pp. 22-39.

19. Dove, J.A., Collins, C.A. and Smith, D.J., 'The Impact of Public Pension Board of Trustee Composition on State Bond Ratings', 2018, Economics of Governance, vol. 19, no. 1, pp. 51-73.

20. Erie, S.P., Kogan, V. and MacKenzie, S.A., Paradise Plundered: Fiscal Crisis and Governance Failures in San Diego, Stanford, CA: Stanford University Press, 2011.

21. Farmer, L. and Maciag, M., 'Why Some Public Pensions Could Soon Look Much Worse', Governing, March 17, 2015, [Online] available at http://www.governing.com/topics/mgmt/ gov-gasb-pension-plans-may-look-worse-soon.html, accessed on September 11, 2015.

22. Fiscal Survey of States, National Association of State Budget Officers, 2016, [Online] available at http://www.nasbo.org/publications-data/fiscal-survey-of-the-states/archives, accessed on September 4, 2018.

23. Fitzpatrick, T.J. and Monahan, A.B., 'Who's Afraid of Good Governance? State Fiscal Crises, Public Pension Underfunding, and the Resistance to Governance Reform', 2015, Florida Law Review, vol. 66, no. 3, pp. 1317-1371.

24. Glaeser, E.L. and Ponzetto, G.A.M., 'Shrouded Costs of Government: The Political Economy of State and Local Public Pensions', 2014, Journal of Public Economics, vol. 116, pp. 89-105.

25. Goldhaber, D., Grout, C. and Holden, K.L., 'Pension Structure and Employee Turnover', 2017, ILR Review, vol. 70, no. 4, pp. 976-1007.

26. Greenhut, S., Plunder!: How Public Employee Unions Are Raiding Treasuries Controlling Our Lives and Bankrupting the Nation, Santa Ana, CA: Forum Press, 2009.

27. Hess, D., 'Protecting and Politicizing Public Pension Fund Assets: Empirical Evidence on the Effects of Governance Structures and Practices', 2005, U.C. Davis Law Review, vol. 39, pp. 187-227.

28. Hirsch, B.T. and MacPherson, D.A., 'Union Membership and Coverage Database from the Current Population Survey: Note', 2003, ILR Review, vol. 56, no. 2, pp. 349-354.

29. Kallen, C., 'State Tax and Expenditure Limitation and Supermajority Requirement: New and Updated Data', AEI Economics Working Paper 2017-19, 2017, [Online] available at http://www.aei.org/publication/state-tax-and-expenditure-limitations-and-supermajori ty-requirements-new-and-updated-data/, accessed on July 31, 2018.

30. Kelley, D.G., 'The Political Economy of Unfunded Public Pension Liabilities', 2014, Public Choice, vol. 158, no. 1/2, pp. 21-38.

31. Kiewiet, D.R., 'The Day after Tomorrow: The Politics of Public Employee Benefits', 2010, California fournal of Politics and Policy, vol. 2, no. 3, pp. 1-30.

32. Kmenta, J., Elements of Econometrics, $2^{\text {nd }}$ edition, New York: Macmillan, 1986. 
33. Liang, K.Y. and Zeger, S.L., 'Longitudinal Data Analysis Using Generalized Linear Models', 1986, Biometrika, vol. 73, no. 1, pp. 13-22.

34. Lowenstein, R., While America Aged: How Pension Debts Ruined General Motors, Stopped the NYC Subways, Bankrupted San Diego, and Loom as the Next Financial Crisis, New York: The Penguin Press, 2008.

35. Lucas, D.J. and Zeldes, S.P., 'How Should Public Pension Plans Invest', 2009, The American Economic Review, vol. 99, no. 2, pp. 527-532.

36. Malanga, S., 'The Beholden State: How Public-sector Unions Broke California', City fournal. Spring 2010, [Online] available at http://city-journal.org/2010/20_2_california-unions. html, accessed on March 21, 2014.

37. Marschall, M.J. and Ruhil, A.V.S., 'Fiscal Effects of the Voter Initiative Reconsidered: Addressing Endogeneity', 2005, State Politics and Policy Quarterly, vol. 5, no. 4, pp. 327-355.

38. Martin, I.W., The Permanent Tax Revolt: How the Property Tax Transformed American Politics, Stanford, CA: Stanford University Press, 2008.

39. Mason, K.C., 'Panel's Report: Tax Limitations Jeopardize State's Economic Future', 2005, State Tax Notes, vol. 37, pp. 487-488.

40. Mathews, J. and Paul, M., California Crackup: How Reform Broke the Golden State and How We Can Fix It, Berkeley, CA: University of California Press, 2010.

41. Matsusaka, J.G., 'Fiscal Effects of the Voter Initiative: Evidence from the Last 30 Years', 1995, The fournal of Political Economy, vol. 103, no. 3, pp. 587-623.

42. McGuire, T.J. and Rueben, K.S., 'The Colorado Revenue Limit: The Economic Effects of TABOR', 2006, State Tax Notes, May 8, p. 459.

43. Mitchell, O.S. and Smith, R.S., 'Pension Funding in the Public Sector', 1994, Review of Economics and Statistics, vol. 76, no. 2, pp. 278-290.

44. Monahan, A.B., 'Public Pension Plan Reform: The Legal Framework', 2010, Education Finance and Policy, vol. 5, no. 4, pp. 617-646.

45. Monahan, A.B., 'State Fiscal Constitutions and the Law and Politics of Public Pensions', 2015, University of Illinois Law Review, vol. 4, pp. 117-176.

46. Monahan, A.B., 'Statutes as Contracts? The 'California Rule' and Its Impact on Public Pension Reform', 2012, Iowa Law Review, vol. 97, no. 4, pp. 1029-1083.

47. Monahan, A.B., 'When a Promise Is Not a Promise: Chicago-style Pensions', 2017, UCLA Law Review, vol. 64, pp. 356-413.

48. Mullins, D.R. and Joyce, P.G., 'Tax and Expenditure Limitations and State and Local Fiscal Structure: An Empirical Assessment', 1996, Public Budgeting and Finance, vol. 16, no. 1, pp. 75-101.

49. Munnell A.H, Aubry, J.P., Hurwitz, J. and Quinby, L., 'Union and Public Pension Benefits', State and Local Pension Plans, Center for Retirement Research at Boston College, July 2011b, [Online] available at http://crr.bc.edu/wp-content/uploads/2011/07/slp_19-508.pdf, accessed on September 5, 2013.

50. Munnell, A.H., Aubry, J.P. and Quinby, L., 'Public Pension Funding in Practice', 2011a, Journal of Pension Economics and Finance, vol. 10, no. 2, pp. 247-268.

51. Munnell, A.H., Haverstick, K. and Mauricio, S., 'Why Have Defined Benefit Plans Survived in the Public Sector?', Center for Retirement Research at Boston College, December 2007, [Online] available at http://crr.bc.edu/briefs/why-have-defined-benefit-plans-survived-inthe-public-sector/, accessed on May 5, 2015. 
52. Munnell, A.H., State and Local Pensions: What Now?, Washington, D.C.: Brookings Institution Press, 2012.

53. National Council of State Legislature, 'State Partisan Composition', 2015, [Online] available at http://www.ncsl.org/research/about-state-legislatures/partisan-composition.aspx, accessed on August 13, 2018.

54. Novy-Marx, R. and Rauh, J., 'Public Pension Promises: How Big Are They and What Are They Worth?', 2011, Journal of Finance, vol. 66, no. 4, pp. 1211-1249.

55. Novy-Marx, R. and Rauh, J.D., 'The Liabilities and Risks of State-sponsored Pension Plans', 2009, Journal of Economic Perspectives, vol. 23, no. 4, pp. 191-210.

56. Pennacchi, G. and Rastad, M., 'Portfolio Allocation for Public Pension Funds', 2011, fournal of Public Economics and Finance, vol. 10, no. 2, pp. 221-245.

57. Pollack, S.D., Refinancing America: The Republican Antitax Agenda, Albany, N.Y.: State University of New York Press, 2003.

58. Poterba, J.M., 'Budget Institutions and Fiscal Policy in the U.S. States', 1996, American Economic Review, vol. 86, no. 2, pp. 395-400.

59. Poterba, J.M., 'State Responses to Fiscal Crises: The Effects of Budgetary Institutions and Politics', 1994, Journal of Political Economy, vol. 102, no. 4, pp. 799-821.

60. Public Plans Data, 2001-2016, Center for Retirement Research at Boston College, Center for State and Local Government Excellence, and National Association of State Retirement Administrators, [Online] available at https://crr.bc.edu/data/public-plans-database/, accessed on September 10, 2018.

61. Raman, K.K. and Wilson, E.R., 'The Debt Equivalence of Unfunded Government Pension Obligations', 1990, fournal of Accounting and Public Policy, vol. 9, no. 1, pp. 37-56.

62. Rose, S., 'Do Fiscal Rules Dampen the Political Business Cycle?', 2006, Public Choice, vol. 128, no. 3-4, pp. 407-431.

63. Schieber, S.J., 'Political Economy of Public Sector Retirement Plans', 2011, fournal of Pension Economics and Finance, vol. 10, no. 2, pp. 269-290.

64. Schneider, M. and Damanpour, F., 'Public Choice Economics and Public Pension Plan Funding', 2002, Administration and Society, vol. 34, no. 1, pp. 57-86.

65. Shadbegian, R.J., 'The Effect of Tax and Expenditure Limitations on the Revenue Structure of Local Government, 1962-87’, 1999, National Tax fournal, vol. 52, no. 2, pp. 221-238.

66. The Economist, 'State Pensions in America: Ruinous Promises', June 15, 2013, [Online] available at http://www.economist.com/news/leaders/21579463-states-cannot-pretend-begood-financial-health-unless-they-tackle-pensions-ruinous-promises, accessed on June 17, 2013.

67. The Pew Charitable Trusts, 'The State Pension Funding Gap: 2016', April 2018, [Online] available at https://www.pewtrusts.org/en/research-and-analysis/issue-briefs/2018/04/thestate-pension-funding-gap-2016, accessed on August 3, 2018.

68. The Pew Charitable Trusts, 'The State Pensions Funding Gap: Challenges Persist', July 2015, [Online] available at http://www.pewtrusts.org/en/research-and-analysis/issue-bri efs/2015/07/the-state-pensions-funding-gap-challenges-persist, accessed on November 3, 2016.

69. Thom, M., 'All of the Above: How Fiscal, Political, and Workforce Traits Affect Pension Funding', 2013b, State and Local Government Review, vol. 45, no. 3, pp. 163-171. 
70. Thom, M., 'Politics, Fiscal Necessity, or Both? Factors Driving the Enactment of Defined Contribution Accounts for Public Employees', 2013a, Public Administration Review, vol. 73, no. 3, pp. 480-489.

71. U.S. Census Bureau, '2015 Census of Governments. Surveys of State and Local Government Finances', 2016, [Online] available at http://www.census.gov//govs/local/, accessed on August 15, 2018.

72. Waring, M.B., Pension Finance: Putting the Risks and Costs of Defined Benefit Plans Back under Your Control, Hoboken, N.J.: Wiley \& Sons, 2012.

73. Wilson, E.R. and Howard, T.P., 'The Association between Municipal Market Measures and Selected Financial Reporting Practices: Additional Evidence', 1984, fournal of Accounting Research, vol. 22, no. 1, pp. 207-224.

74. Wilson, E.R., 'Fiscal Performance and Municipal Bond Borrowing Costs', 1983, Public Budgeting and Finance, vol. 3, no. 4, pp. 28-41.

75. Zeger, S.L. and Liang, K.Y., 'Longitudinal Data Analysis for Discrete and Continuous Outcomes', 1986, Biometric Society, vol. 42, no. 1, pp. 121-130.

76. Zorn, C., 'Generalized Estimating Equation Models for Correlated Data: A Review with Applications', 2001, American fournal of Political Science, vol. 45, no. 2, pp. 470-490. 